\title{
Endothelial differentiation of bone marrow mesenchyme stem cells applicable to hypoxia and increased migration through Akt and NFKB signals
}

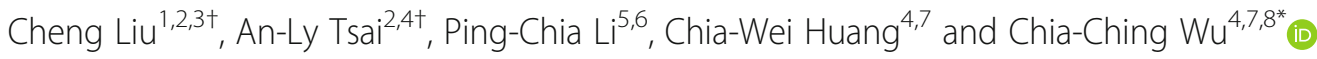

\begin{abstract}
Background: Bone marrow mesenchymal stem cells (MSCS) and endothelial progenitor cells (EPCs) are used to repair hypoxic or ischemic tissue. However, the underlining mechanism of resistance in the hypoxic microenvironment and the efficacy of migration to the injured tissue are still unknown. The current study aims to understand the hypoxia resistance and migration ability of MSCs during differentiation toward endothelial lineages by biochemical and mechanical stimuli.

Method: MSCs were harvested from the bone marrow of 6-8-week-old Sprague-Dawley rats. The endothelial growth medium (EGM) was added to MSCs for 3 days to initiate endothelial differentiation. Laminar shear stress was used as the fluid mechanical stimulation.

Results: Application of EGM facilitated the early endothelial lineage cells (eELCs) to express EPC markers. When treating the hypoxic mimetic desferrioxamine, both MSCs and eELCs showed resistance to hypoxia as compared with the occurrence of apoptosis in rat fibroblasts. The eELCs under hypoxia increased the wound closure and C-X-C chemokine receptor type 4 (CXCR4) gene expression. Although the shear stress promoted eELC maturation and aligned cells parallel to the flow direction, their migration ability was not superior to that of eELCs either under normoxia or hypoxia. The eELCs showed higher protein expressions of CXCR4, phosphorylated Akt (pAkt), and endogenous NFkB and IkBa than MSCs under both normoxia and hypoxia conditions. The potential migratory signals were discovered by inhibiting either Akt or NFkB using specific inhibitors and revealed decreases of wound closure and transmigration ability in eELCs.

Conclusion: The Akt and NFkB pathways are important to regulate the early endothelial differentiation and its migratory ability under a hypoxic microenvironment.
\end{abstract}

Keywords: Stem cell, Endothelial differentiation, Hypoxia, Migration, Akt, Nuclear factor-kB

\section{Background}

Hypoxic or ischemic injury causes cell death by oxidative stress and cellular signals to trigger tissue necrosis and subsequently life-long dysfunctions [1-5]. The injured tissues produce cytokines and chemokines to recruit stem or progenitor cells for repairing the damaged sites. However, the number of endogenous therapeutic cells is

\footnotetext{
* Correspondence: joshccwu@mail.ncku.edu.tw

${ }^{\dagger}$ Equal contributors

${ }^{4}$ Department of Cell Biology and Anatomy, College of Medicine, National Cheng Kung University, Tainan, Taiwan

${ }^{7}$ Institute of Basic Medical Sciences, College of Medicine, National Cheng Kung University, Tainan, Taiwan

Full list of author information is available at the end of the article
}

usually not sufficient to recover a large injury site. Stem or progenitor cells have been applied to rescue ischemic injury in clinical trials, such as myocardial infarction or stroke [6, 7]. Bone marrow mesenchymal stem cells (MSCs) have the characteristics of self-renewal and multipotency [8-10]. MSCs are potent therapeutic sources to differentiate or transdifferentiate into other therapeutic lineages for neovascular genesis of new vessels to repair damaged tissues [11-13].

Cell apoptosis under hypoxia is regulated by mitogenactivated protein kinase (MAPK), nuclear factor- $k B$ (NFkB), phosphatidylinositol 3-kinase (PI3K)/Akt, or the release of cytochrome $\mathrm{C}$ to activate the apoptotic 
cascades $[14,15]$. Under hypoxia, reactive oxygen species are produced to degrade the NFKB inhibitor (IкB) into RelA/p50 dimer for nuclear translocation. Hypoxia also regulates hypoxia inducible factor-1 (HIF-1) activity via PI3K/Akt or MAPK signaling in an oxygen-independent manner. The interaction and crosstalk of HIF-1 and NFKB signals are important for immune responses, inflammation, and anti-apoptosis [16].

In hypoxic tissue, stromal cell-derived factor-1 (SDF-1) and $\mathrm{C}-\mathrm{X}-\mathrm{C}$ chemokine receptor type 4 (CXCR4) are important factors for cell migration. The damaged tissues secrete SDF-1 to attract CXCR4-expressed cells, particularly the therapeutic progenitors [17]. Conversely, MSCs originate from the bone marrow microenvironmental niche with exhibiting of low oxygen tension $[18,19]$. Invitro culture of MSCs under hypoxic conditions (low oxygen tension) showed benefits in maintaining cell selfrenewal, migration, vascular tube formation, and release of paracrine factors for chemotactic and proangiogenic properties [20-22]. Endothelial progenitor cells (EPCs) are classified into early EPCs and late EPCs which can be isolated from peripheral blood or bone marrow [23, 24]. Upon tissue damage, EPCs are mobilized from the bone marrow and migrated into the hypoxic region to regenerate the vascular structure and restore tissue function $[25,26]$. EPCs participate in the reendothelialization of angiogenesis as well as of vasculogenesis by differentiating into mature endothelial cells (ECs) [27-29]. For the injected EPCs, recruitment and incorporation into the ischemic region is essential for achieving the beneficial outcomes [30,31]. However, the migration and functional roles of therapeutic cells in MSCs as well as in different stages of EPCs under a hypoxic microenvironment are still not clear.

The combination of biochemical and mechanical stimuli promotes several adult stem cells, including placentaderived multipotent cells (PDMCs) [32] and adiposederived stem cells (ASCs) [33, 34], to switch their MSC characteristics toward endothelial lineage cells (ELCs). ELCs are defined as mixture cells for cell transplantation without sorting of different endothelial populations after endothelial differentiation [33]. The application of endothelial growth medium (EGM) to these adult stem cells induces expression of early EPC markers named early ELCs (eELCs). After a subsequent mechanical stimulation of laminar shear stress (LSS), ELCs showed mature EC characteristics of forming vascular tube-like stucture and uptake of lipoproteins [32]. However, the differentiation of MSCs using this approach and their characteristics under hypoxia are still unknown. Desferrioxamine (DFO), an iron chelator, is known to upregulate hypoxia signals by stabilizing the HIF-1 activity [35] and to reduce free radical-mediated cell injury [36]. In the current study, we are interested to know the anti-apoptosis and migration abilities of MSCs and their differentiated ELCs under hypoxic microenvironments. We hypothesize that MSCs and their ELCs can resist hypoxia and able to migrate toward the injury site via a specific signaling pathway for repairing the damaged tissue. The understanding of cellular responses and potential signals for hypoxia in MSCs and ELCs may benefit the clinical preconditioning of these therapeutic cells for better repair outcomes.

\section{Methods}

\section{Cell culture and differentiation}

Bone marrow-derived MSCs were harvested from femoral bone marrow of 8-week-old Sprague-Dawley (SD) rats. Briefly, the cells were flushed from the femoral bone and collected into Dulbecco's modified Eagle medium (DMEM; Invitrogen) supplemented with 10\% fetal bovine serum (FBS; Hyclone) and 1\% penicillinstreptomycin (Invitrogen), and seeded on a $100-\mathrm{mm}$ Petri dish. The detached cells were removed after culture for $24 \mathrm{hr}$. The adhered cells were characterized and defined as rat MSCs after confirmation of stem cell markers and differentiation ability [32]. The MSCs were used between passages 2 and 5 in the current study. The NRK49F fibroblast cell line (ATCC) was cultured in DMEM supplement with 10\% FBS and 1\% penicillinstreptomycin to represent the rat stromal cells. To induce endothelial differentiation, eELCs were induced by culturing MSCs in medium 199 (M199; Invitrogen) supplemented with 20\% FBS, EGM (Lonza), and 1\% penicillin-streptomycin under a static condition for 3 days [32, 34]. The maturation of ELCs was induced by subjecting the eELCs to LSS $\left(12 \mathrm{dyn} / \mathrm{cm}^{2}\right)$ for $24 \mathrm{hr}$ using the flow chamber system [32].

\section{Cell treatments under in-vitro hypoxic microenvironments} The hypoxic mimetic DFO (Sigma-Aldrich) was used to create an in-vitro hypoxic microenvironment with different dosages $(10,20,50 \mu \mathrm{M})$ [37]. The fibroblasts, MSCs, and differentiated cells were rinsed with phosphatebuffered saline (PBS) and then exchanged to fresh DMEM containing 1\% FBS and different dosages of DFO. The hypoxic microenvironment was also created by placing cells in a hypoxia incubator (Autoflow 4950; NuAire Inc.) and reducing the oxygen concentration to $2 \%$. Low oxygen tension hypoxia was created by mixing $5 \% \mathrm{CO}_{2}$ and replacing oxygen with $\mathrm{N}_{2}$ in the hypoxia incubator. Upon blockage of potential signaling pathways using specific inhibitors, the CXCR4 signal was inhibited by CXCR4 antagonist AMD3100 (Sigma-Aldrich). The PI3K/Akt inhibitor LY294006 (10 $\mu \mathrm{M}$; Sigma-Aldrich) and the antioxidant pyrrolidinedithiocarbamate (PDTC, $10 \mu \mathrm{M}$; Sigma-Aldrich) were used to inhibit Akt phosphorylation and NFKB activity, respectively. To abolish 
the stimulation upon DFO application, cells were pretreated with specific inhibitors (LY294006, PDTC, or AMD3100) for $30 \mathrm{~min}$, and then DFO applied for the indicated time.

\section{Flow cytometry assessments}

Flow cytometry was used to quantify the cell apoptosis and CD surface markers. The early stage of cell apoptosis was further confirmed using flow cytometry and by positive staining with annexin $\mathrm{V}$ and negative staining with propidium iodide (PI) [38]. The fibroblasts, MSCs, and eELCs treated with DFO were resuspended and incubated with fluorescein isothiocyanate (FITC)-labeled annexin V antibody and PI (Strong Biotech Corporation) in the dark at $4{ }^{\circ} \mathrm{C}$ for $15 \mathrm{~min}$. The labeled cells were measured by flow cytometry (FACScan; BD Biosciences) and analyzed by WinMDI software. Percentages of cells with positive staining for annexin $\mathrm{V}$ and negative staining for PI were calculated to identify the apoptotic cells.

To quantify the MSC characteristics, the specific antibodies against CD34 (1:40; Abcam), CD45 (1:100; BD Pharmingen), and CD90 (1:50; BD Pharmingen) were measured in MSCs, eELCs, and fibroblasts. Antibodies for Flt (VEGFR1, 1:100; Abcam) and Flk (VEGFR2, 1:100; Abcam) were used as the positive markers for early EPCs, whereas PECAM-1 (CD31, 1:40; BD Pharmingen) was labeled for the late EPCs or mature ECs. In brief, the trypsinized cells were incubated with specific antibodies in the dark at $4{ }^{\circ} \mathrm{C}$ for $30 \mathrm{~min}$ and then rinsed with wash buffer (PBS with $0.2 \%$ BSA) by short centrifuge. The fluorescent intensities of labeled cells were quantified by flow cytometry (FACS Calibur; BD Biosciences), counting 10,000 cells in each sample. The NRK49F fibroblast was defined as the negative stained threshold to distinguish the positive cells in MSCs and eELCs.

\section{Measurement of gene and protein expressions}

The reverse transcription polymerized chain reaction (RT-PCR) and quantitative real-time PCR (qPCR) were performed to measure the gene (mRNA) expressions according to a previous study [32]. Briefly, the cells were lysed by Trizol (Invitrogen) to isolate the mRNA and then reverse transcripted into cDNA using Super Script III (Invitrogen). The specific gene expressions were amplified and detected by the Taq-PCR (GeneDirex) system with specific primers [33]. For qPCR, the SYBR ${ }^{\mathrm{mm}}$ green master mix (Thermo Fisher) was used to amplify the specific genes with forward $(F)$ and reverse $(R)$ primer sequences for Flt (F: GAAGAGTGGGTCGTCATTCC, R: GTAGCC ATGCACCGAATAGC), Flk (F: CGGGA AACTACACGGTCATC, R: GGGAGGGTT GGCATA GACT), von Willebrand factor ( $v W F$ ) (F: CAGGGCTC TACCAGGATGAA, R: TTTGCTGCGGTG AGACAA), and GAPDH (F: TGCCACTCAGAAGACTGTGG, R: ACGGATACATTG GGGGTAGG). The relative gene expressions were calculated using the $2^{-\Delta \Delta \mathrm{Ct}}$ method normalized to the housekeeping gene GAPDH. The endothelial differentiation was further confirmed by the expression levels of early EPC markers for Flt and Flk. $v W F$ and PECAM-1 were used to indicate the gene expression of mature EC markers.

The protein expressions for intracellular signaling were assessed by western blotting. The cells were rinsed twice with cold PBS and then lysed with RIPA buffer containing protease inhibitors. Cell lysates were analyzed by sodium dodecyl sulfate polyacrylamide gel electrophoresis (SDSPAGE) with $10 \%$ cross-linking gel, and then transferred into nitrocellulose membranes (Bio-Rad). The membranes were blocked by $5 \%$ dry milk in TBS with $0.5 \%$ Tween 20 for $90 \mathrm{~min}$. For specific protein detection, membranes were hybridized with specific primary antibodies overnight at $4{ }^{\circ} \mathrm{C}$. Bound primary antibodies were detected using appropriate secondary antibodies coupled to horseradish peroxidase (Sigma-Aldrich) and by an ECL detection system (Millipore). The antibody against poly-ADP ribose polymerase (PARP, 1:1000; Cell Signaling), a downstream protein which is cleaved in apoptotic cell via caspase signals, was used to detect the cleaved PARP for indicating cell apoptosis. The expression of CXCR4 was assessed by specific CXCR4 antibody (1:1000; Abcam). The phosphorylation levels of Akt signal were detected by the antibody against the phospho-Akt (pAkt, 1:500; Cell Signaling) and normalized to total form Akt (tAkt, 1:100; Santa Cruz) protein. $\mathrm{NFkB}$ signaling was measured by $\mathrm{NF \kappa B}$ p 65 (1:500; Santa Cruz) and IкB $\alpha$ (1:500; Santa Cruz) antibody. The fold changes of cleaved PARP, NFkB p65, and IкB $\alpha$ were normalized to $\beta$-actin. The nuclear and cytoplasmic fractions were extracted using a nuclear and cytoplasmic extraction kit (G-Biosciences) to demonstrate the nuclear translocation of $\mathrm{NFKB}$ in accordance with the user instructions. Lamin A/C antibody (1:500; Santa Cruz) was used to indicate the successful isolation of nuclear protein in western blotting.

\section{Assessment of cell migration ability}

The ability of stem cells to migrate into the lesion site is important for tissue protection and regeneration. We utilized wound closure and Boyden chamber assays to assess the migration of MSCs and ELCs. For the wound closure assay, the MSCs and differentiated ELCs were cultured on a six-well plate until full confluence and then created a "wound" by scratching a gap using a pipette tip. After rinsing with PBS, cells were then incubated in fresh DMEM with or without DFO for $24 \mathrm{hr}$. For treatment with inhibitors, the inhibitors were applied to the confluent cells for $30 \mathrm{~min}$ to create a wound for cells to close under normoxia or hypoxia 
conditions. The phase images for wounds were recorded at 0 and $24 \mathrm{hr}$ by ImageJ software (Image J). The percentage of wound closure (\%) was measured by quantifying wound areas at $24 \mathrm{hr}\left(\mathrm{A}_{24}\right)$ and deductive to the initial time points $\left(\mathrm{A}_{0}\right)$ using the equation $\left(\mathrm{A}_{0}-\mathrm{A}_{24}\right) / \mathrm{A}_{0}$ [39].

The Boyden chamber (48-Well Micro Chemotaxis Chamber; Neuro Probe) was used to detect chemotaxis and transmigration in MSCs and endothelial differentiated cells. Cells were resuspended and counted for $4 \times 10^{5}$ cells $/ \mathrm{ml}$ to load into the upper compartment of the Boyden chamber. The migration ability was measured by counting the cells that migrated through $8-\mu \mathrm{m}$ pore membranes (Neuro Probe) to the lower compartment after incubation for $6 \mathrm{hr}$ with medium with or without $50 \mu \mathrm{M}$ of DFO. Specific inhibitors were pretreated to the cells for $30 \mathrm{~min}$ before resuspending and loading into the Boyden chamber. The transmigration was quantified after dissembling the chamber, fixing cells with $4 \%$ paraformaldehyde for $5 \mathrm{~min}$, and then staining with Giemsa for $15 \mathrm{~min}$. Images were taken by microscope (CX31; Olympus) and quantified using
ImageJ software (ImageJ) with normalizing to the transmigrated cell numbers under normoxia (without DFO).

\section{Statistical analyses}

For all experiments, at least three independent groups were performed to demonstrate a consistent outcome. All data were expressed as the mean \pm standard SEM. Statistical analysis was performed using one-way analysis of variance (ANOVA) and $p<0.05$ was considered statistically significant using Origin statistical software (version 8.5; OriginLab).

\section{Results}

MSCs and early differentiated ELCs resistant to hypoxia than somatic cells

The MSC surface CD markers were observed by positive staining of CD90 (98.41\%) and negative staining of CD34, CD45, Flt, Flk, and CD31 in MSCs (Fig. 1a). The eELCs were differentiated by culturing the MSCs in EGM for 3 days. The early EPC markers were increased for both Flt (41.09\%) and Flk (42.29\%) in eELCs as

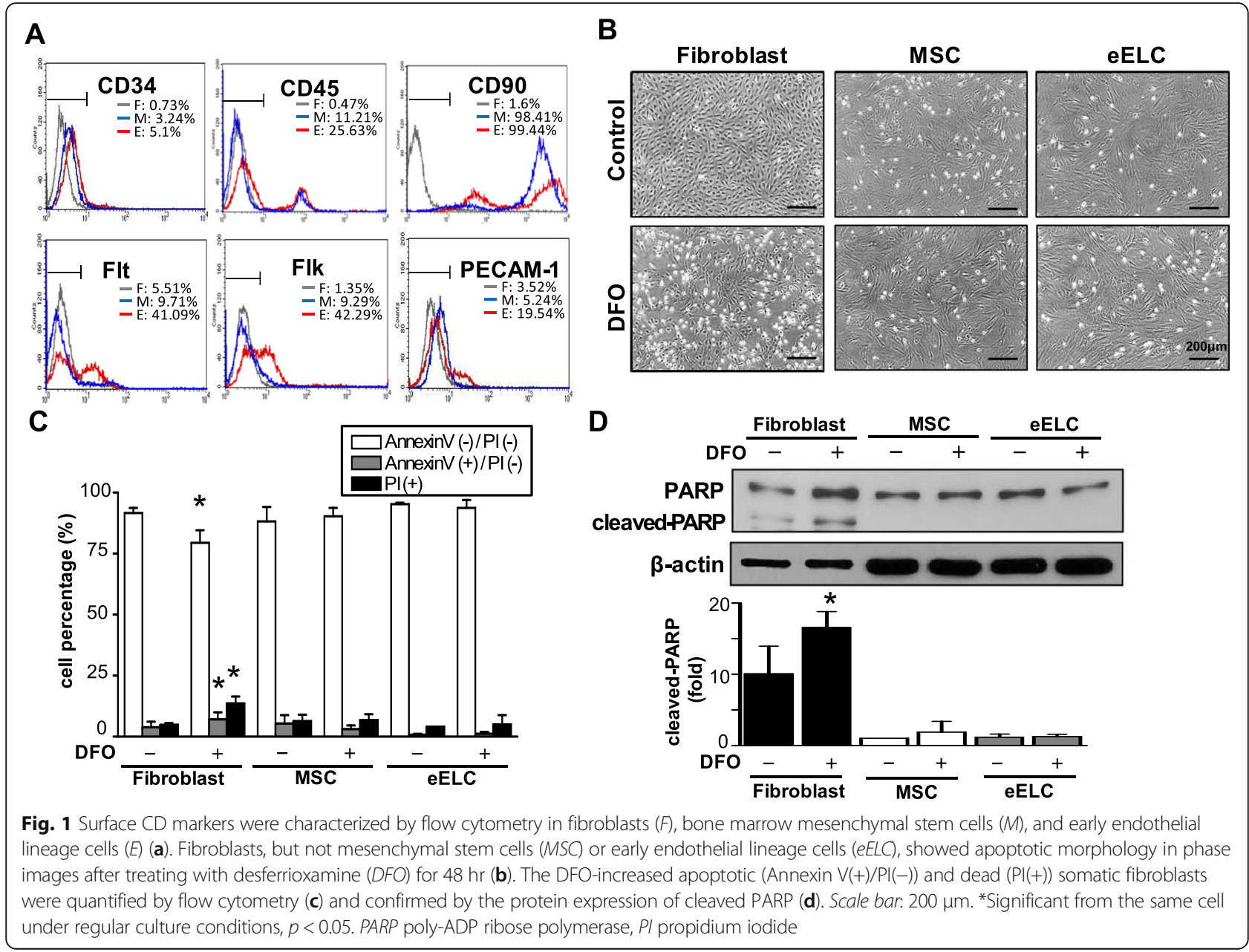


compared with the expression patterns in MSCs. The eELCs also showed a partial increase of PECAM-1positive cells (19.54\%). Although the CD90 intensity slightly decreased in eELCs, the protein expression level was still showed positive as compared with the negative stained fibroblasts.

To understand the effect of hypoxia in MSCs and their derived cells, DFO $(50 \mu \mathrm{M})$ was treated for $48 \mathrm{hr}$ and significant cellular morphological changes were not observed in MSCs and eELCs as compared with the rat fibroblasts (Fig. 1b). However, membrane blebbing and shrinkage of the cell body were observed in fibroblasts, suggesting that DFO might cause cell damage or apoptosis in somatic cells. The annexin V/PI double staining flow cytometry was used to assess the cell apoptosis and death under DFO treatment (Fig. 1c). In regular culture condition (normoxia), the fibroblasts, MSCs, and eELCs have more than $90 \%$ living cells (annexin V/PI doublenegative). The living fibroblasts were significantly decreased after hypoxia (DFO) for $48 \mathrm{hr}$ and switched to the early apoptotic cells (annexin V-positive/PI-negative) and dead cells (PI-positive) (Fig. 1c). On the contrary, no significant difference of MSCs and eELCs occurred after treatment with DFO. Cleaved PARP was observed and confirmed the hypoxia-induced cell apoptosis in fibroblasts, but not in either MSCs or eELCs (Fig. 1d). These results suggest that MSCs are resisted to the hypoxic microenvironments and the early differentiation of ELCs also endures in DFO treatment.

\section{Hypoxic microenvironment enhanced migration of eELCs}

Treatment of DFO for $24 \mathrm{hr}$ in eELCs further enhanced endothelial gene expressions, especially in the mature EC marker vWF (Fig. 2a). The qPCR results showed that the increase of Flt gene expression in eELCs was inhibited after DFO treatment, but Flk gene expression was relatively increased in both MSCs and eELCs. We were further interested to know the beneficial effects of hypoxia in eELCs. Cell migration was measured by wound closure assay in both MSCs and eELCs with different dosages of DFO $(0,10,20,50 \mu \mathrm{M})$. The MSCs and eELCs showed similar proliferation potential as indicated by BrdU and Ki67 staining (Additional file 1: Figure S1). Under normoxia (without DFO), the eELCs already showed a better wound closure rate than MSCs at $24 \mathrm{hr}$ after wounding (Fig. 2b). The MSCs showed about 37\% of closure by migrating into the empty wound area, whereas the eELCs presented around $63 \%$ of wound closure migration. With DFO treatment at 20 and $50 \mu \mathrm{M}$, eELC migration to close the wound increased to about $80 \%$ and showed a dose-dependent manner. DFO treatment also increased minor cell migration in MSCs, but not as obvious as that in eELCs. Because SDF-1/CXCR4 chemotaxis plays a critical role in stem/progenitor cell migration, we further

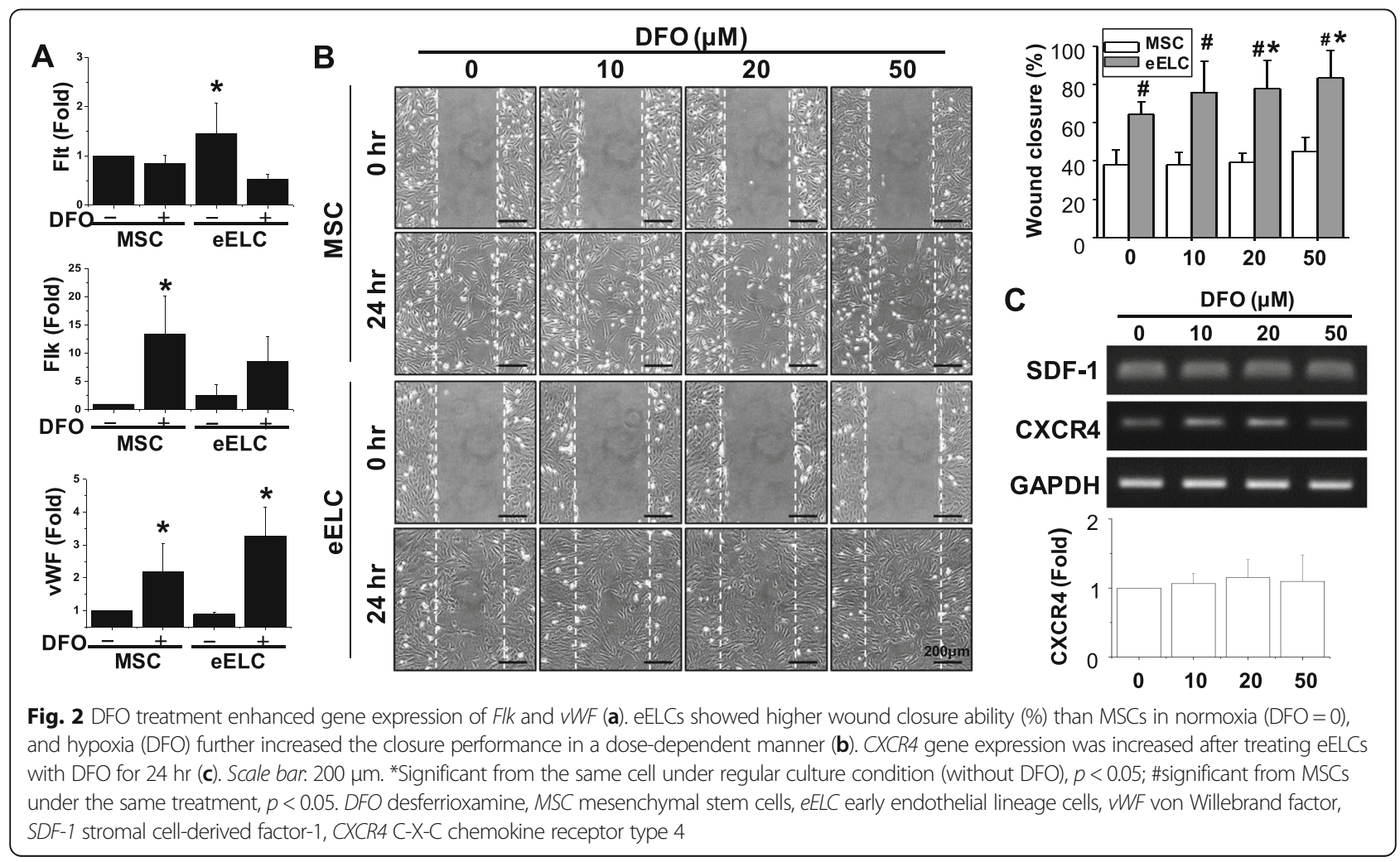


assessed the gene expression of SDF-1 and CXCR4 with different dosages of DFO. The chemoattractant SDF-1 level showed no difference, but its receptor CXCR4 was upregulated in responding to the DFO dosage (Fig. 2c).

\section{Shear stress promoted ELC maturation, but decreased cell migration ability}

Because shear stress may provide the synergistic effect in endothelial differentiation for other adult stem cells $[32,33]$, we assessed the interaction of DFO and LSS $\left(12 \mathrm{dyn} / \mathrm{cm}^{2}\right)$ in both MSCs and eELCs. Either DFO or LSS treatment increased the VEGFA mRNA expressions in MSCs, but their combination did not show further enhancement of VEGFA (Fig. 3a). VEGFA also increased in eELCs after treatment with DFO or LSS. On the contrary, the combination of DFO and LSS increased the mature EC marker, PECAM-1, in MSCs. LSS alone induced PECAM-1 expression which suggests that shear stress can promote the maturation of eELCs. After applying LSS for $24 \mathrm{hr}$, the phase-contrast cell images showed a parallel orientation of elongated eELCs to indicate their responses to the flow as mature endothelium (Fig. 3b). The occurrence of DFO during LSS stimulation did not alter eELC morphology. Although LSS promoted eELC maturation, these mature cells showed decreases of transmigration abilities (stained cells) regardless of DFO treatment in the Boyden chamber assay (Fig. 3c). These results suggest that mature ECs do not enhance their migration ability as compared with the early ELCs under either the normoxia or hypoxia condition.

\section{Involvement of Akt and NFKB signals in eELC migration}

To understand potential signaling for the enhancement of migration in eELCs, total proteins were isolated from MSCs and eELCs with or without DFO treatment. The eELCs showed higher CXCR4 protein expression than MSCs under both normoxia and hypoxia conditions (Fig. 4a). The potential intracellular pathways were assessed by observing the Akt, NFkB p65, and IкB $\alpha$ signals in MSCs and eELCs (Fig. 4b). In MSCs, phosphoAkt (pAkt) was increased under DFO treatment for $24 \mathrm{hr}$. The eELCs showed higher protein expression levels in pAkt, NFкB p65, and IкB $\alpha$ than MSCs. However, the application of DFO did not alter these protein expressions in eELCs. We further used LY294002 (LY) to inhibit PI3K/Akt signals and the PDTC to block the $\mathrm{NF} \mathrm{B}$ pathway with or without the presence of DFO (Fig. 5a). Both the LY and PDTC treatments did not increase cleaved PARP in eELCs under either the normoxia or hypoxia condition. CXCR4 protein expression was decreased with LY or PDTC treatment, showing that pAkt and NFkB signals might regulate CXCR4. The inhibition of PI3K/Akt or NFKB signals in eELCs inhibited the nuclear translocation of NFKB p65 (Fig. 5b). The promotion of the wound closure ability in eELCs under DFO treatment was inhibited by LY (significant deferent

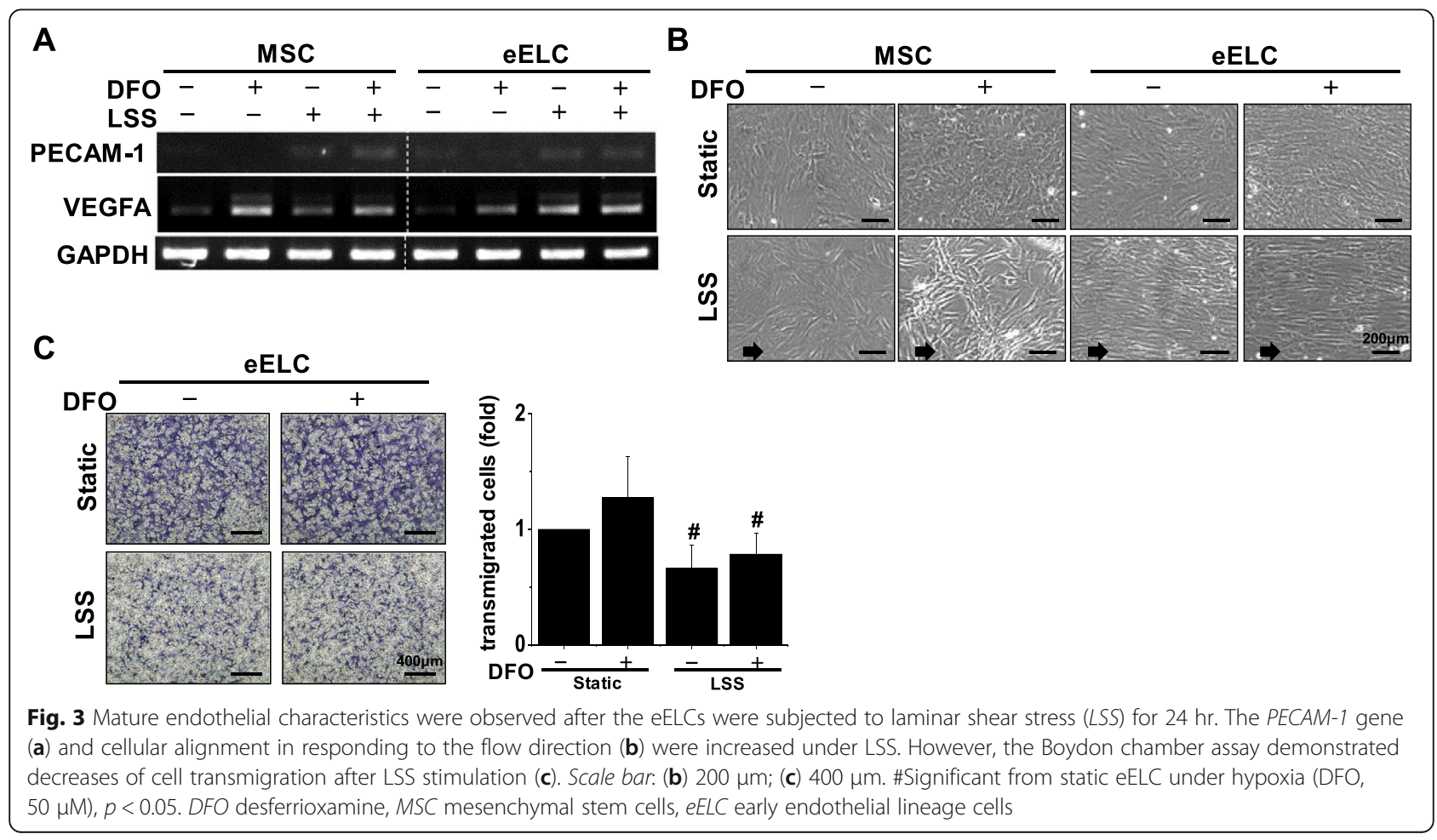



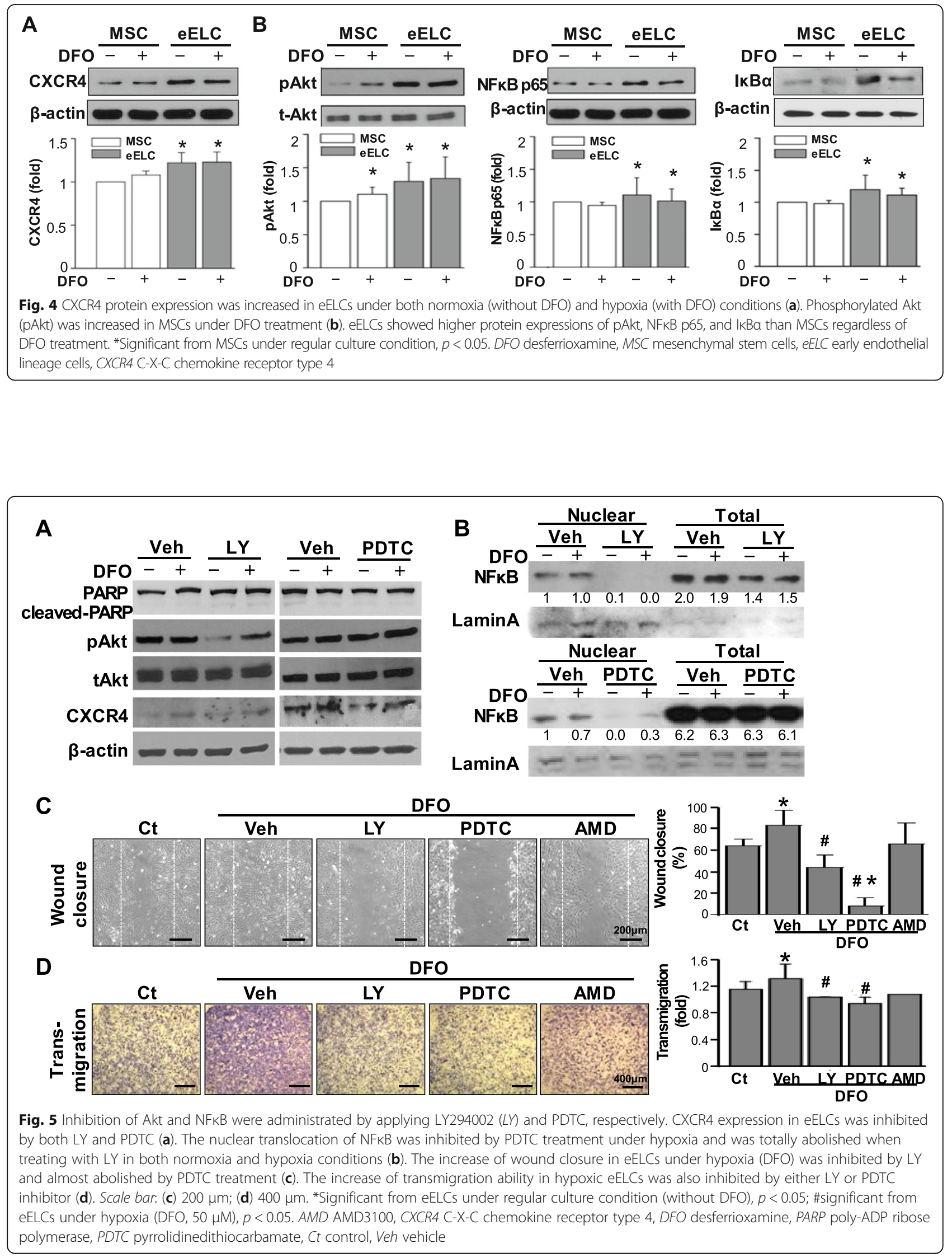
to hypoxia) and totally abolished by PDTC (significant different to both normoxia and hypoxia) (Fig. 5c). The transmigration of eELCs also diminished under both PDTC and LY treatments (Fig. 5d). We also tested the CXCR4 antagonist AMD3100 (AMD) in hypoxic eELCs, but did not observe significant inhibition of wound closure or transmigration ability. Taken together, these results indicated the involvement of Akt and $\mathrm{NFKB}$ signaling to regulate CXCR4 protein expression for the migration ability of eELCs.

\section{Discussion}

Hypoxic-ischemic injury in stroke and myocardial infarction is well known with many stem cell treatments. Nowadays, combinations with different gene manipulations or drug preconditions in stem/progenitor cells are mostly used to study the therapeutic effect on in-vivo ischemic injury [40-42]. However, the concern of gene manipulation and its safety for transplanting cells are always raised in clinical trials. Hence, the current study prefers to induce MSCs toward the endothelial lineage via the culture medium that contains endothelial growth factors.

Ischemia, including hypoxia, serum deprivation, and glucose deprivation, is usually involved in injured tissues. HIF-1 is a critical transcription factor in the hypoxic environment. The HIF-1 $\alpha$ subunit (HIF- $1 \alpha$ ) has a very short half-life in a normoxic environment which can be degraded by oxygen-dependent prolyl hydroxylase domain enzymes through the ubiquitin-proteasome pathway [43]. DFO and cobalt chloride $\left(\mathrm{CoCl}_{2}\right)$ can stabilize HIF-1 protein for mimic hypoxia conditions in vitro. Other in-vitro hypoxia models were generated by reducing the oxygen content from 10 to $1 \%[44,45]$ or deprivation of serum to damage stem/progenitor cells [21]. However, the hypoxia model using serum deprivation induced MSCs to undergo apoptosis and might not represent a physiological condition because serum is present in our body composition [46]. In this study, we use DFO to mimic an in-vitro hypoxic condition which aligned with the data from our previous study [37]. Our data suggested that hypoxia created by DFO increased cell migration, especially in eELCs. We also incubated the MSCs and eELCs in a low-oxygen hypoxia chamber and obtained similar results (Additional file 2: Figure S2). The hypoxic microenvironments enhanced the 3D encapsulated MSCs to promote the outgrowth of tube-like structures in PEGylated fibrin and to secrete VEGF and MMP2 [47]. In current study, the MSC response under hypoxia was consistent with these published works.

CXCR4 is a seven-transmembrane $\mathrm{G}$ protein-coupled receptor that the binds to SDF-1. SDF-1, also known as CXCL12, is a small secreted chemokine protein belonging to the CXC chemokine family. Several signaling cascades are activated after SDF-1 and CXCR4 form ligand-receptor complexes. The PI3K/Akt/eNOS signal pathway is involved in the SDF-1-induced EPC migration and MSC survival [48, 49]. Our data showed that DFO promotes Akt phosphorylation in MSCs (Fig. 4b) and the higher expression of pAkt for cell migration in ELCs was blocked by Akt inhibitor (Fig. 5). NFkB is a critical transcription factor involved in biological responses which includes immune responses, cell survival, stress responses, and maturation of various cell types. Five subunits of NFkB (RelA (p65), RelB (p100), cRel, p50, and p52) generate different dimeric complexes, and control cellular function through canonical or noncanonical pathways [50]. IкB phosphorylates and inactivates the $N_{F} B$ signal for inflammatory and survival gene transcriptions. Under hypoxia, HIF- $1 \alpha$ was correlated with $\mathrm{NF \kappa B}$ due to the inhibition of oxygendependent hydroxylases for activation of both the HIF-1 and $\mathrm{NF \kappa B}$ pathways [16, 51]. Although our results showed that $\mathrm{NF \kappa B}$ and IкB were not altered by DFO treatment in both MSCs and eELCs (Fig. 4b), the DFOmediated cell migration was abolished by inhibiting the NFKB signaling using PDTC (Fig. 5). The results of decreasing the $\mathrm{NFkB}$ nuclear translation under both Akt and $\mathrm{NF}_{\mathrm{K} B}$ inhibitor treatments confirmed the essential role of $A k t / N F K B$ signaling in eELC migration.

Besides the migration ability for therapeutic cell homing to the damaged tissue, the angiogenesis process is also very important for repairing injury. The reendothelialization capacity was improved by recruiting EPCs via CXCR4 [52] and PI3K/Akt [53] signaling. Overexpression of CXCR4 in MSCs facilitated the treatment of acute lung injury in rats [54]. The angiogenic function of EPCs also associated with PI3K/Akt when treating the conditioned medium isolated from multipotent stromal cells [15]. We demonstrated an increase of CXCR4 and pAkt protein expressions in eELCs (Fig. 4) which might benefit the angiogenesis in vivo. Shear stress can also recruit PI3K and induces NFKB translocation and transcriptional activity via the integrins/FAK/actin network $[55,56]$. The importance of mechanical factors on MSC differentiation was summarized in a recent review [57]. LSS, a mechanical force on the straight part of vascular endothelium, has vasoprotective function, suppresses inflammatory response [58], and promotes differentiation and tube formation on EPCs [59]. However, the angiogenic potential and functions in early and late EPCs are divergent [60]. Early EPCs secrete plentiful cytokines, including VEGF, interleukin-8, hepatocyte growth factor, and granulocyte-colony stimulating factor [60, 61], while late ELCs have a better ability in proliferation and endothelial incorporation [60]. In the current study, eELCs showed characteristics similar to early EPCs, whereas 
LSS facilitated these cells toward late EPCs or mature ECs. Although LSS benefits endothelial maturation (Fig. 3), the decrease of transmigration ability after subjecting eELCs to LSS suggested that these endothelial therapeutic cells in a distinct differentiation phase may have a unique role in protecting the vascular structure.

\section{Conclusion}

In this study, we demonstrated that MSCs can differentiate into endothelial lineage and promote migration ability in responding to a hypoxic microenvironment, which might benefit cell therapy and tissue regeneration. DFO is on the List of Essential Medicines as announced by the World Health Organization to demonstrate its safety and importance in medications, especially for treating acute iron poisoning in small children. eELC induction and then preconditioning to DFO can provide a novel and convenientto-clinics therapeutic strategy to increase the function of MSCs. In summary, we conclude the eELCs derived from MSCs may serve as a better source for cell-based therapy regarding hypoxia resistance and migration ability.

\section{Additional files}

Additional file 1: Figure S1. showing similar cell proliferation abilities were observed by $\operatorname{BrdU}(\mathbf{A})$ and Ki67 (B) staining in both MSCs and eELCs. (PDF 161 kb)

Additional file 2: Figure S2. showing the hypoxia incubator has similar gene expression patterns in both MSCs and eELCs as compared withto these observed in DFO treatments (A). Same induction effects of p-Akt in hypoxic MSCs and increase of CXCR4 in eELCs were confirmed when incubating the cells in a low oxygen incubator (B). (PDF $237 \mathrm{~kb}$ )

\section{Acknowledgements}

Not applicable.

\section{Funding}

This study was supported by ChiMei Hospital-NCKU join grant (CMNCKU10306) and in part by grants from the Ministry of Science and Technology (NSC1022320-B-006-009-MY3, MOST104-2320-B-006-043, MOST105-2314-B-006-041-MY5) and the National Health Research Institute (NHRI-EX101-10115EC, EX10510525El) in Taiwan

\section{Availability of data and materials}

Not applicable

\section{Authors' contributions}

$C L, A-L T, P-C L, C-W H$, and $C-C W$ discussed and designed the study. CL, A-LT, and $\mathrm{C}-\mathrm{WH}$ performed the experiments. $\mathrm{CL}, \mathrm{A}-\mathrm{LT}$, and $\mathrm{C}-\mathrm{CW}$ analyzed the results. $C L, A-L T, P-C L$, and $C-C W$ wrote the manuscript. All authors read and approved the final manuscript.

\section{Competing interests}

The authors declare that they have no competing interests.

\section{Consent for publication}

Not applicable

\section{Ethics approval and consent to participate}

The SD rats were provided by the animal center in NCKU with the approval of the experiment procedure by the Institutional Animal Care and Use Committee at NCKU.

\section{Author details}

${ }^{1}$ Hyperbaric Oxygen Therapy Center, Chi-Mei Medical Center, Tainan, Taiwan. ${ }^{2}$ Division of Plastic Surgery, Chi-Mei Medical Center, Tainan, Taiwan.

${ }^{3}$ Department of Electrical Engineering, Southern Taiwan University of Science and Technology, Tainan, Taiwan. ${ }^{4}$ Department of Cell Biology and Anatomy, College of Medicine, National Cheng Kung University, Tainan, Taiwan.

${ }^{5}$ Department of Occupational Therapy, I-Shou University, Kaohsiung, Taiwan. ${ }^{6}$ School of Medicine for International Students, I-Shou University, Kaohsiung, Taiwan. ${ }^{7}$ Institute of Basic Medical Sciences, College of Medicine, National Cheng Kung University, Tainan, Taiwan. ${ }^{8}$ Medical Device Innovation Center, National Cheng Kung University, Tainan, Taiwan.

Received: 28 July 2016 Revised: 21 December 2016 Accepted: 6 January 2017 Published online: 07 February 2017

\section{References}

1. Saito A, Maier CM, Narasimhan P, Nishi T, Song YS, Yu F, Liu J, Lee YS, Nito C, Kamada H, Dodd RL, Hsieh LB, Hassid B, Kim EE, Gonzalez M, Chan PH. Oxidative stress and neuronal death/survival signaling in cerebral ischemia. Mol Neurobiol. 2005;31(1-3):105-16.

2. Song YS, Narasimhan P, Kim GS, Jung JE, Park EH, Chan PH. The role of Akt signaling in oxidative stress mediates NF-kappaB activation in mild transient focal cerebral ischemia. J Cereb Blood Flow Metab. 2008;28(12):1917-26.

3. Matsushita H, Morishita R, Nata T, Aoki M, Nakagami H, Taniyama $Y$, Yamamoto K, Higaki J, Yasufumi K, Ogihara T. Hypoxia-induced endothelial apoptosis through nuclear factor-kappaB (NF-kappaB)-mediated bcl-2 suppression: in vivo evidence of the importance of NF-kappaB in endothelial cell regulation. Circ Res. 2000;86(9):974-81.

4. Aoki M, Nata T, Morishita R, Matsushita H, Nakagami H, Yamamoto K, Yamazaki K, Nakabayashi M, Ogihara T, Kaneda Y. Endothelial apoptosis induced by oxidative stress through activation of NF-kappaB: antiapoptotic effect of antioxidant agents on endothelial cells. Hypertension. 2001;38(1):48-55.

5. Hsueh YY, Wang DH, Huang TC, Chang YJ, Shao WC, Tuan TL, Hughes MW, Wu CC. Novel skin chamber for rat ischemic flap studies in regenerative wound repair. Stem Cell Res Ther. 2016;7(1):72.

6. Zaruba MM, Franz WM. Role of the SDF-1-CXCR4 axis in stem cell-based therapies for ischemic cardiomyopathy. Expert Opin Biol Ther. 2010;10(3):321-35.

7. Losordo DW, Dimmeler S. Therapeutic angiogenesis and vasculogenesis for ischemic disease: part Il: cell-based therapies. Circulation. 2004;109(22):2692-7.

8. Baksh D, Song L, Tuan RS. Adult mesenchymal stem cells: characterization, differentiation, and application in cell and gene therapy. J Cell Mol Med. 2004;8(3):301-16.

9. Herzog EL, Chai L, Krause DS. Plasticity of marrow-derived stem cells. Blood. 2003;102(10):3483-93.

10. Das R, Jahr H, van Osch GJ, Farrell E. The role of hypoxia in bone marrowderived mesenchymal stem cells: considerations for regenerative medicine approaches. Tissue Eng Part B Rev. 2010;16(2):159-68.

11. Silva GV, Litovsky S, Assad JA, Sousa AL, Martin BJ, Vela D, Coulter SC, Lin J, Ober J, Vaughn WK, Branco RV, Oliveira EM, He R, Geng YJ, Willerson JT, Perin EC. Mesenchymal stem cells differentiate into an endothelial phenotype, enhance vascular density, and improve heart function in a canine chronic ischemia model. Circulation. 2005:111(2):150-6.

12. Pittenger MF, Martin BJ. Mesenchymal stem cells and their potential as cardiac therapeutics. Circ Res. 2004;95(1):9-20.

13. Shudo Y, Miyagawa S, Ohkura H, Fukushima S, Saito A, Shiozaki M, Kawaguchi N, Matsuura N, Shimizu T, Okano T, Matsuyama A, Sawa Y. Addition of mesenchymal stem cells enhances the therapeutic effects of skeletal myoblast cell-sheet transplantation in a rat ischemic cardiomyopathy model. Tissue Eng Part A. 2014;20(3-4):728-39.

14. Li H, Tan J, Zou Z, Huang CG, Shi XY. Propofol post-conditioning protects against cardiomyocyte apoptosis in hypoxia/reoxygenation injury by suppressing nuclear factor-kappa B translocation via extracellular signalregulated kinase mitogen-activated protein kinase pathway. Eur J Anaesthesiol. 2011;28(7):525-34.

15. Hung SC, Pochampally RR, Chen SC, Hsu SC, Prockop DJ. Angiogenic effects of human multipotent stromal cell conditioned medium activate the PI3K-Akt pathway in hypoxic endothelial cells to inhibit apoptosis, increase survival, and stimulate angiogenesis. Stem Cells. 2007;25(9):2363-70.

16. Taylor CT, Cummins EP. The role of NF-kappaB in hypoxia-induced gene expression. Ann N Y Acad Sci. 2009;1177:178-84. 
17. Wu CC, Chen YC, Chang YC, Wang LW, Lin YC, Chiang YL, Ho CJ, Huang CC. Human umbilical vein endothelial cells protect against hypoxic-ischemic damage in neonatal brain via stromal cell-derived factor $1 / \mathrm{C}-\mathrm{X}$-C chemokine receptor type 4. Stroke. 2013;44(5):1402-9.

18. Mohyeldin A, Garzon-Muvdi T, Quinones-Hinojosa A. Oxygen in stem cell biology: a critical component of the stem cell niche. Cell Stem Cell. 2010; 7(2):150-61.

19. Harrison JS, Rameshwar P, Chang V, Bandari P. Oxygen saturation in the bone marrow of healthy volunteers. Blood. 2002;99(1):394.

20. Rosova I, Dao M, Capoccia B, Link D, Nolta JA. Hypoxic preconditioning results in increased motility and improved therapeutic potential of human mesenchymal stem cells. Stem Cells. 2008;26(8):2173-82.

21. Annabi B, Lee YT, Turcotte S, Naud E, Desrosiers RR, Champagne M, Eliopoulos N, Galipeau J, Beliveau R. Hypoxia promotes murine bone-marrow-derived stromal cell migration and tube formation. Stem Cells. 2003;21(3):337-47.

22. Paquet J, Deschepper M, Moya A, Logeart-Avramoglou D, Boisson-Vidal C, Petite H. Oxygen tension regulates human mesenchymal stem cell paracrine functions. Stem Cells Transl Med. 2015;4(7):809-21.

23. Asahara T, Murohara T, Sullivan A, Silver M, van der Zee R, Li T, Witzenbichler B, Schatteman G, Isner JM. Isolation of putative progenitor endothelial cells for angiogenesis. Science. 1997;275(5302):964-7.

24. Kwon SM, Lee YK, Yokoyama A, Jung SY, Masuda H, Kawamoto A, Lee YM, Asahara T. Differential activity of bone marrow hematopoietic stem cell subpopulations for EPC development and ischemic neovascularization. J Mol Cell Cardiol. 2011;51(3):308-17.

25. Asahara T, Takahashi T, Masuda H, Kalka C, Chen D, Iwaguro H, Inai Y, Silver M, Isner JM. VEGF contributes to postnatal neovascularization by mobilizing bone marrow-derived endothelial progenitor cells. EMBO J. 1999;18(14):3964-72.

26. Rabbany SY, Heissig B, Hattori K, Rafii S. Molecular pathways regulating mobilization of marrow-derived stem cells for tissue revascularization. Trends Mol Med. 2003;9(3):109-17.

27. Hristov M, Erl W, Weber PC. Endothelial progenitor cells: mobilization, differentiation, and homing. Arterioscler Thromb Vasc Biol. 2003;23(7):1185-9.

28. Kawamoto A, Gwon HC, Iwaguro H, Yamaguchi II, Uchida S, Masuda H, Silver M, Ma H, Kearney M, Isner JM, Asahara T. Therapeutic potential of ex vivo expanded endothelial progenitor cells for myocardial ischemia. Circulation. 2001;103(5):634-7.

29. Kalka C, Masuda H, Takahashi T, Kalka-Moll WM, Silver M, Kearney M, Li T, Isner JM, Asahara T. Transplantation of ex vivo expanded endothelial progenitor cells for therapeutic neovascularization. Proc Natl Acad Sci U S A. 2000;97(7):3422-7.

30. Rafii S, Lyden D. Therapeutic stem and progenitor cell transplantation for organ vascularization and regeneration. Nat Med. 2003;9(6):702-12.

31. Zhan $\mathrm{K}$, Bai L, Xu J. Role of vascular endothelial progenitor cells in construction of new vascular loop. Microvasc Res. 2013:90:1-11.

32. Wu C-C, Chao Y-C, Chen C-N, Chien S, Chen Y-C, Chien C-C, Chiu J-J, Linju YB. Synergism of biochemical and mechanical stimuli in the differentiation of human placenta-derived multipotent cells into endothelial cells. J Biomech. 2008:41(4):813-21.

33. Huang CW, Huang CC, Chen YL, Fan SC, Hsueh YY, Ho CJ, Wu CC. Shear stress induces differentiation of endothelial lineage cells to protect neonatal brain from hypoxic-ischemic injury through NRP1 and VEGFR2 signaling. Biomed Res Int. 2015;2015:862485.

34. Hsueh YY, Chang YJ, Huang CW, Handayani F, Chiang YL, Fan SC, Ho CJ, Kuo YM, Yang SH, Chen YL, Lin SC, Huang CC, Wu CC. Synergy of endothelial and neural progenitor cells from adipose-derived stem cells to preserve neurovascular structures in rat hypoxic-ischemic brain injury. Sci Rep. 2015;5:14985.

35. Wang GL, Semenza GL. Desferrioxamine induces erythropoietin gene expression and hypoxia-inducible factor 1 DNA-binding activity: implications for models of hypoxia signal transduction. Blood. 1993;82(12):3610-5.

36. Woo KJ, Lee TJ, Park JW, Kwon TK. Desferrioxamine, an iron chelator, enhances HIF-1alpha accumulation via cyclooxygenase-2 signaling pathway. Biochem Biophys Res Commun. 2006;343(1):8-14.

37. Liu C, Tsai AL, Chen YC, Fan SC, Huang CH, Wu CC, Chang CH. Facilitation of human osteoblast apoptosis by sulindac and indomethacin under hypoxic injury. J Cell Biochem. 2012;113(1):148-55.

38. Wu CC, Li YS, Haga JH, Kaunas R, Chiu JJ, Su FC, Usami S, Chien S. Directional shear flow and Rho activation prevent the endothelial cell apoptosis induced by micropatterned anisotropic geometry. Proc Natl Acad Sci U S A. 2007; 104(4):1254-9.
39. Bai SW, Herrera-Abreu MT, Rohn JL, Racine V, Tajadura V, Suryavanshi N, Bechtel S, Wiemann S, Baum B, Ridley AJ. Identification and characterization of a set of conserved and new regulators of cytoskeletal organization, cell morphology and migration. BMC Biol. 2011;9:54.

40. Grochot-Przeczek A, Dulak J, Jozkowicz A. Therapeutic angiogenesis for revascularization in peripheral artery disease. Gene. 2013;525(2):220-8.

41. Liu Q, Xi Y, Terry T, So SP, Mohite A, Zhang J, Wu G, Liu X, Cheng J, Ruan KH, Willerson JT, Dixon RA. Engineered endothelial progenitor cells that overexpress prostacyclin protect vascular cells. J Cell Physiol. 2012;227(7):2907-16.

42. Cao G, Liu C, Wan Z, Liu K, Sun H, Sun X, Tang M, Bing W, Wu S, Pang X, Zhang X. Combined hypoxia inducible factor-1alpha and homogeneous endothelial progenitor cell therapy attenuates shunt flow-induced pulmonary arterial hypertension in rabbits. J Thorac Cardiovasc Surg. 2015;150(3):621-32.

43. Weidemann A, Johnson RS. Biology of HIF-1alpha. Cell Death Differ. 2008; 15(4):621-7.

44. Lee SP, Youn SW, Cho HJ, Li L, Kim TY, Yook HS, Chung JW, Hur J, Yoon CH, Park KW, Oh BH, Park YB, Kim HS. Integrin-linked kinase, a hypoxia-responsive molecule, controls postnatal vasculogenesis by recruitment of endothelial progenitor cells to ischemic tissue. Circulation. 2006;114(2):150-9.

45. Schroder K, Kohnen A, Aicher A, Liehn EA, Buchse T, Stein S, Weber C, Dimmeler S, Brandes RP. NADPH oxidase Nox2 is required for hypoxia-induced mobilization of endothelial progenitor cells. Circ Res. 2009;105(6):537-44.

46. Deng J, Han Y, Yan C, Tian X, Tao J, Kang J, Li S. Overexpressing cellular repressor of E1A-stimulated genes protects mesenchymal stem cells against hypoxia- and serum deprivation-induced apoptosis by activation of PI3K Akt. Apoptosis. 2010;15(4):463-73.

47. Rytlewski JA, Alejandra Aldon M, Lewis EW, Suggs LJ. Mechanisms of tubulogenesis and endothelial phenotype expression by MSCs. Microvasc Res. 2015;99:26-35.

48. Yin Q, Jin P, Liu X, Wei H, Lin X, Chi C, Liu Y, Sun C, Wei Y. SDF-1alpha inhibits hypoxia and serum deprivation-induced apoptosis in mesenchymal stem cells through PI3K/Akt and ERK1/2 signaling pathways. Mol Biol Rep. 2011:38(1):9-16.

49. Zheng H, Fu G, Dai T, Huang H. Migration of endothelial progenitor cells mediated by stromal cell-derived factor-1alpha/CXCR4 via PI3K/Akt/eNOS signal transduction pathway. J Cardiovasc Pharmacol. 2007;50(3):274-80.

50. Ridder DA, Schwaninger M. NF-kappaB signaling in cerebral ischemia. Neuroscience. 2009;158(3):995-1006.

51. Culver C, Sundqvist A, Mudie S, Melvin A, Xirodimas D, Rocha S. Mechanism of hypoxia-induced NF-kappaB. Mol Cell Biol. 2010;30(20):4901-21.

52. Tang YL, Zhu W, Cheng M, Chen L, Zhang J, Sun T, Kishore R, Phillips MI, Losordo DW, Qin G. Hypoxic preconditioning enhances the benefit of cardiac progenitor cell therapy for treatment of myocardial infarction by inducing CXCR4 expression. Circ Res. 2009;104(10):1209-16.

53. Hur J, Yoon CH, Lee CS, Kim TY, Oh IY, Park KW, Kim JH, Lee HS, Kang $\mathrm{HJ}$, Chae IH, Oh BH, Park YB, Kim HS. Akt is a key modulator of endothelial progenitor cell trafficking in ischemic muscle. Stem Cells. 2007;25(7):1769-78

54. Yang JX, Zhang N, Wang HW, Gao P, Yang QP, Wen QP. CXCR4 receptor overexpression in mesenchymal stem cells facilitates treatment of acute lung injury in rats. J Biol Chem. 2015;290(4):1994-2006.

55. Wang Y, Flores L, Lu S, Miao H, Li YS, Chien S. Shear stress regulates the Flk-1/Cbl/PI3K/NF-kappaB pathway via actin and tyrosine kinases. Cell Mol Bioeng. 2009;2(3):341-50.

56. Petzold T, Orr AW, Hahn C, Jhaveri KA, Parsons JT, Schwartz MA. Focal adhesion kinase modulates activation of NF-kappaB by flow in endothelial cells. Am J Physiol Cell Physiol. 2009;297(4):C814-22.

57. Dan $\mathrm{P}$, Velot $\mathrm{E}$, Decot $\mathrm{V}$, Menu P. The role of mechanical stimuli in the vascular differentiation of mesenchymal stem cells. J Cell Sci. 2015;128(14):2415-22.

58. Chang YJ, Huang HC, Hsueh YY, Wang SW, Su FC, Chang CH, Tang MJ, Li YS, Wang SH, Shung KK, Chien S, Wu CC. Role of excessive autophagy induced by mechanical overload in vein graft neointima formation: prediction and prevention. Sci Rep. 2016;6:22147.

59. Yamamoto K, Takahashi T, Asahara T, Ohura N, Sokabe T, Kamiya A, Ando J. Proliferation, differentiation, and tube formation by endothelial progenitor cells in response to shear stress. J Appl Physiol. 2003;95(5): 2081-8. 
60. Hur J, Yoon C-H, Kim H-S, Choi J-H, Kang H-J, Hwang K-K, Oh B-H, Lee M-M, Park Y-B. Characterization of two types of endothelial progenitor cells and their different contributions to neovasculogenesis. Arterioscler Thromb Vasc Biol. 2004;24(2):288-93.

61. Rehman J, Li J, Orschell CM, March KL. Peripheral blood "endothelial progenitor cells" are derived from monocyte/macrophages and secrete angiogenic growth factors. Circulation. 2003;107(8):1164-9.

Submit your next manuscript to BioMed Central and we will help you at every step:

- We accept pre-submission inquiries

- Our selector tool helps you to find the most relevant journal

- We provide round the clock customer support

- Convenient online submission

- Thorough peer review

- Inclusion in PubMed and all major indexing services

- Maximum visibility for your research

Submit your manuscript at www.biomedcentral.com/submit 